\title{
In-vivo and in-vitro evaluation of pharmacological activities of Ardisia solanacea leaf extract
}

\author{
Mohammad Rashedul Islam', Jannatul Naima', Nawreen Monir Proma', Md. Saddam Hussain², \\ S. M. Naim Uddin ${ }^{1}$ and Mohammed Kamrul Hossain ${ }^{1 *}$
}

\begin{abstract}
Background: The Bangladeshi rural and hilly areas people have long tradition to use various medicinal plants for treating different diseases. That's why, the crude methanolic leaf extract of Ardisia solanacea with its different fractions (petroleum ether, carbon tetrachloride, $\mathrm{n}$-hexane and chloroform fractions) were subjected to investigate bioactivities in swiss albino mice; namely analgesic, CNS, and Oral hypoglycemic activities, while in-vitro evaluation of cytotoxicity.

Methods: Central nervous system activity was investigated by various method such as Elevated plus maze, Hole board, Hole cross and Open field test apparatus. Analgesic activity was evaluated by both acetic acid induced and tail immersion method. Hypoglycemic activity was evaluated by oral glucose tolerance test and cytotoxicity was evaluated by Brine shrimp lethality bioassay.

Results: In CNS activity, among others fractions, ASCF fraction produced a significant anxiolytic activity in both elevated plus maze and Hole board test. During open-field test almost all the fractions of $A$. solanacea leaves extract display decreased locomotor activities that indicates significant sedative activity. The ASME and ASCF showed significant peripheral analgesic activity at a dose of $200 \mathrm{mg} / \mathrm{kg}$ and $400 \mathrm{mg} / \mathrm{kg}$ body weight $(p<0.05)$. In tail immersion method, among others extracts chloroform fractions exhibited significant $(p<0.05)$ elongation of reaction time 30 min after oral dose of 200 and $400 \mathrm{mg} / \mathrm{kg}$ body weight respectively. The methanolic and $\mathrm{n}$-hexane extracts reduced blood glucose level significantly after 90 min with value of $53.94 \%$ and $48.15 \%$ respectively $(p<0.05)$. In case of cytotoxicity activity, among other fractions carbon tetrachloride fraction showed lowest $L C_{50}$ values.
\end{abstract}

Conclusions: From the above results, it is clear that different fractions of $A$. solanacea showed significant pharmacological potentiality in different in-vitro and in-vivo study model. So, it will be very much possible source for an isolating lead compound for curing the numerous disorders.

Keywords: Phytochemicals, Central nervous system, Analgesic, Hypoglycemic, Cytotoxicity

\section{Background}

Using of complementary medicine to alleviate and improve health conditions in developed countries are increasing [1]. Keeping this purpose in mind, new medicinal plants from different areas of the universe is being investigated [2]. Now-a-days most of the people prefer the alternative medicine on account of its fewer toxic effects and health hazards [3].

\footnotetext{
* Correspondence: mkhossain73@yahoo.com

${ }^{1}$ Department of Pharmacy, University of Chittagong, Chittagong 4331, Bangladesh

Full list of author information is available at the end of the article
}

Traditional medicine of Bangladesh is a unique conglomerate of different ethnomedical consequences. Because of geographic location and socioculturals characteristics of the country, it comprises traditionaly rooted elements influenced by local instinctive people, and also cover-by Indian Unani and Ayurveda medicine $[4,5]$. The plants having phytochemicals possess medicinal value that can have physiological and pharmacological actions on human body $[6,7]$. Genus, Ardisia is the leading genus of Myrsinaceae family. About 500 species of evergreen trees and shrubs are commenced throughout the tropical and 
sub-tropical regions of the universe [8]. Besides, $A$. compressa possesses significant hypoglycemic effects in Type 2 diabetic rats, and antioxidant activity and A. crispa showed in vitro cytotoxic activity and antioxidative actions against breast cancer cell lines [9]. Barks and leaves of $A$. colorata were extracted with ethanol having antimicrobial activities [10]. The present study protocol is designed to investigate phytochemical and pharmacological properties of $A$. solanacea leaves. A. solanacea Roxb. (Family: Primulaceae; sub-family Myrsinoideae) is a glabrous shrub or small tree that reaches a maximum height of $20 \mathrm{ft}$ under habitat conditions. The plant has potential pharmaceutical applications (such as antibacterial and antiviral properties) from extracts of plants from the genus Ardisia were noted by Kobayashi and de Mejia [11]. More specifically, antibacterial activity against four serovars of salmonella were observed with plant extracts from A. solanacea [12] and there were positive effects on the reduction of breast cancer cells [13]. The variety of ethnopharmacological uses and phytoconsituents had led our attraction to investigate phytochemicals and pharmacological properties of this plant.

\section{Materials and methods}

Plant material

Plant sample of $A$. solanacea was collected from Hilly area of Chittagong in July 2017. Then taxonomist Dr. Shaikh Bokhtiar Uddin, Professor, Department of Botany, University of Chittagong, identified it.

\section{Preparation of the plant material}

The whole plant part of A. solanacea leaves was washed properly, cut into small pieces, and then air dried for several days. After proper air-drying, the small pieces were then grinded into coarse powder with the help of grinding machine in the Phytochemical Research Laboratory, Pharmacy department, University of Chittagong. The materials then were stored into air resistant container.

\section{Extraction of the plant material}

About $700 \mathrm{~g}$ of the powdered material was taken in a clean, round bottomed flask (5l) and soaked in $3.5 \mathrm{l}$ of pure methanol (Merck KGaA, Germany). The reservoir with its content was sealed by foil and kept for 15-20 days by occasional stirring and shaking. The whole mixture was then filtered through a fresh cotton plug and finally with a Whitman No.1 filters paper. The volume of the filtrate was then reduced using a Buchii Rota (Cole-Parmer, UK) evaporator at low temperature and pressure. The weight of extract yielded was $42.42 \mathrm{~g}$. The percentage yield of the extract was calculated using the following equation [14]:

$\%$ of yield of extracts $=\frac{\text { Weight of extracted material }}{\text { Weight of original plant material used }} \times 100$

\section{Phytochemical screening of the compound}

Phytochemical analysis of the methanolic extracts of $A$. solanacea and its different soluble fractions were conducted using the standard procedures to identify various constituents described by Sofowara, Trease and Evans, and Harborne [15-17].

\section{Experimental animals}

Young male Swiss-albino mice, aged 3-4 weeks with an average weight $20-25 \mathrm{~g}$, were collected from the Bangladesh Council of Scientific and Industrial Research Laboratories (BCSIR) and animal house of Pharmacy Department, Jahangirnagar University. The animals were housed comfortably in a group of six in a single clean plastic cage with a metal net structured frame lid on its top. They were kept in standard environmental condition (temperature: $\left(24 \pm 1{ }^{\circ} \mathrm{C}\right.$ ), relative humidity: $55 \%-65 \%$ and $12 \mathrm{~h}$ light dark/ $12 \mathrm{~h}$ dark circle) for one week in the animal house of the Pharmacy Department, University of Chittagong, Bangladesh for adaptation. The animals were provided with standard laboratory food and water.

\section{Study design}

For both anxiolytic and sedative activities, fifty experimental animals were selected, numbered, weighed and divided into ten groups. Group (I) was treated as control (saline), group (II) for standard drug (Diazepam; $1.0 \mathrm{mg}$ / $\mathrm{kg}$ ) treatment and others group for different doses (200 and $400 \mathrm{mg} / \mathrm{kg}$ ) of methanolic extract of $A$. solanacea leaves and n-hexane, carbon tetrachloride and chloroform carbon tetrachloride fractions respectively and for the both central and peripheral analgesic activities, forty mices were selected randomly and grouped into eight. They were fasted for $12 \mathrm{~h}$ and later treated as follows: group (I) was treated as control (1\% Tween 80 in normal saline; $0.1 \mathrm{ml} / 10 \mathrm{~g}$ ), group (II) for standard drug (Diclofenac sodium; $50 \mathrm{mg} / \mathrm{kg}$ ) treatment and others group for different doses (200 and $400 \mathrm{mg} / \mathrm{kg}$ ) of methanolic extract of $A$. solanacea leaves and of its $\mathrm{n}$-hexane and chloroform fraction respectively. In oral hypoglycemic activity, 25 experimental animals were randomly selected and divided into four groups. Here, group (I) served as control and received vehicle (1\% Tween 80 in saline, 10 $\mathrm{ml} / \mathrm{kg}$ body weight), group (II) received standard drug (Glibenclamide, $2 \mathrm{mg} / \mathrm{kg}$ ) and the four other groups received the sample extract at four different doses. Each experimental group comprising five mice's. All the test samples, control, and standard were administered orally. 


\section{Evaluation of anxiolytic activity}

\section{Elevated plus maze method}

Elevated plus maze is very important apparatus to investigate anxiolytic response [18] as well as neuroprotective actions created by the test drugs. Animals that are exposed to novel maze avenue invites a way- repeal combat that is stronger in open arm as compared to closed arm. Rodents, which have an aversion for high and open space and put forward to enclosed arm, consequently pass a greater amount of time in enclosed arm. Animals, when enter into open arm, they become freeze, immobile, defecate and exhibit fear-like behaviors [19]. An actual reflection of anxiety is reported due to increase level of plasma cortisol. Further, merits of this test procedure: (a) it is fast, simple and less time-consuming, (b) noxious stimuli or training is not required and (c) this is reliable and predictable for perusing anxiety properties as well as anxiolytic activity of drug [20,21]. Elevated plus maze apparatus is designed as a + shape, consisting of two open arms $(25 \times 5 \mathrm{~cm}$, with a very slight, $0.5-\mathrm{cm}$, wall) across from each other and perpendicular to two closed arms $(25 \times 5 \times 16 \mathrm{~cm})$, and is raised $40 \mathrm{~cm}$ above the floor [22]. Experimental animals were installed individually in the center of the maze, head that is facing towards open arm and stopwatch was started. The subsequent parameters were observed for 5 min. (1) At first we see, mouse is preferred to either open arm or close arm, (2) Counting of entries into open arm and closed arm; when four paws of mouse is entered into an arm is called arm entry. Control (saline), Standard (Diazepam), and other test samples of $A$. solanacea leaves were administered to the animals. After $30 \mathrm{~min}$, animals were installed individually in the middle of the maze. In the end, the animals which were preferred to either open or closed arm, the average time spent in the open arm entries number in each testing group was compared.

\section{Hole-board test method}

Hole-board apparatus consists of an enclosed arena with holes in the floor into which an animal can poke its head, referred to as head-dipping [23]. Measurement of neophilia or directed exploration is obtained from the duration and frequency of head dipping. This indicates the general locomotor function of the animal is independent [24]. The increased level head dipping generally indicate neophilia, when low level are tend to result from absence of neophilia or tend to indicate an increased anxiety-like state in the testing animals [25]. Therefore, the anxiety state is increased as the number and incidence of head dipping is reduced and vice-versa [26]. 30 mins prior to treatment with control, standards and test samples, the mice were installed singly on the hole board apparatus, and we counted the head dipping of mice into the holes at the altitude of their eyes during 5 mins trial period using a tally counter.

\section{Evaluation of sedative activity Open-field test method}

This test was carried out in apparatus having a floor of about half-square meter in area and surrounded by a wall of $50 \mathrm{~cm}$ in height [27]. The floor is made of small squares alternately which is colored in white and black. The number of squares visited by the mice was counted and noted for an interval of $3 \mathrm{~min}$ (counted using a tally counter); at $0,30,60,90$ and $120 \mathrm{~min}$; of the oral administration of the control (saline), Standard (Diazepam) and the test samples of different doses (200 and $400 \mathrm{mg} / \mathrm{kg}$ ).

\section{Hole-crossed test apparatus}

This test was carried out in a closed chamber having a size of $(30 \mathrm{~cm} \times 20 \mathrm{~cm} \times 14 \mathrm{~cm})$ surrounded by wooden walls, no rooftop [28]. The chamber is partitioned in the central portion by placing a fixed wooden structure. The fixed wooden partitioned had a round hole curve in it; diameter of $3.5 \mathrm{~cm}$ at a height of the hole is $7.5 \mathrm{~cm}$. The mice were crossed through the hole from one chamber to another and by using a tally counter, the number of crossing was counted for 3 mins at $0,30,90,120$ mins intervals respectively.

\section{Evaluation of peripheral analgesic activity Acetic acid writhing method}

Analgesic activity of this plant extract is assessed by acetic acid writhing method $[29,30]$. In this test, acetic acid was used to trigger pain sensation in animals through intraperitoneal administration and as a result, body of animals squirms at regular interval to get away of pain. This continuous contraction or squirms of the animal body is termed as "Writhing". They continue to generate writhing as long as they feel pain. Any extract with analgesic property will give lesser number of writhes in animals with respect to control group. After 40 mins, acetic acid (0.7\%) at the dose of $0.1 \mathrm{ml} / 10 \mathrm{~g}$ body weight was injected by intraperitoneally to all testing animals of different group. The number of writhing or squirms responses generated by each animal was recorded for fifteen minutes just after 5 min of acetic acid injection. The following equation was used for the measurement of percent inhibition of abdominal writhing: \% inhibition of abdominal writhing $=\left[\left(\mathrm{Wc}_{\mathrm{c}}\right.\right.$ $\mathrm{Wt}$ )/Wc $\times 100]$,

Where Wc stands for number of writhing's of control group, and Wt stands for number of writhing's of test group.

\section{Evaluation of central analgesic activity Tail immersion test}

Tail immersion test is a thermal method to evaluate central analgesic activity of methanolic extract, nhexane and chloroform soluble fractions of $A$. solanacea leaves. The test is designed based on the effect of centrally working analgesic drugs, which are 
increasing the time of reaction in animal (mice) in response to hot water on water bath. The present test is done by the method described by Uma devi and Di stasi [31,32]. The mice in each group was held in a suitable restrainer with the whole tail extending out immersed in a water bath thermostatically maintained at $51 \pm 1{ }^{\circ} \mathrm{C} .2-3 \mathrm{~cm}$ of tail of the mices pre-treated with control, Standard and test samples were immersed in hot water of water bath. The time between immersion and deflection of tail was recorded as reaction time or tail-flick latency. Then, latency period was observed at 30, 60, 90 and 120 mins of oral administration. A cut of period of $15 \mathrm{~s}$ were observed to avert tail tissue destruction of mices. Baseline response at 30 mins, mices were tested for twice prior to drug administration. Three measurements were obtained from the baseline reaction time (Latency). After each measurement, animals were gone back to the observation chambers for 2 mins. The mean of these measurements is used to calculate pre-drug latency period. After baseline, the treated mices were tested at 30,60, 90, 120 mins. Finally, the percentage of the Maximal Possible Effect (\%MPE) was calculated using the following equation [33]. \% Of MPE $=\{$ (Post drug latency-Pre drug latency)/(Cut off time-Pre drug latency) $\} \times 100$.

The percentage of time elongation of tail immersion was calculated in respect to the control in respective time. If the percentage of elongation period is higher, the central analgesic action will be greater. The percentage of time elongation was calculated from the following equation [34]. \% of Elongation $=\{$ (Latency of test sample- Latency of control)/ Latency of test sample $\} \times 100$.

\section{Evaluation of hypoglycemic activity}

A glucose tolerance test is one of the most acceptable methods to evaluate the hypoglycemic activity. This test was performed following the procedure described by Joy and Kuttan [35] with slight modification. After 30 mins of extract administration, all groups were treated with $10 \%$ glucose solution ( $2 \mathrm{~g} / \mathrm{kg}$ body weight). After 30,90 and $120 \mathrm{~min}$ of glucose loading, blood samples were collected from tail vein. By using glucometer blood glucose level is measured. Test samples, control, and glibenclamide were given orally. Before any test, every mouse was weighed appropriately and the doses of the test samples and control materials were fitted properly.

\section{In-vitro evaluation of cytotoxic activity}

Cytotoxic activity of this plant was predicted by using the brine shrimp lethality bioassay $[36,37]$.

\section{Preparation of seawater}

$38 \mathrm{~g}$ of pure $\mathrm{NaCl}$ (Salt) weighed properly, dissolved into $1 \mathrm{l}$ of seawater and then filtered the solution to get clean and transparent solution.

\section{Hatching of brine shrimps}

The test organism named as A. salina leach (brine shrimp eggs) was collect from pet shop. Prepared seawater was taken into a small tank and brine shrimp eggs were employed to one edge of the tank that then was covered with a lid. Shrimps in this tank were hatched for two days to give mature shrimp named as nauplii. During this hatching, constant oxygen was supplied and the hatched shrimps were enticed to the lamp through the perforated dam. Ten living matured nauplii were transferred to individual test tube by the help of Pasteur pipette.

\section{Procedure}

$5 \mathrm{mg}$ of all individual samples were dissolved in $1 \mathrm{ml}$ of pure DMSO (dimethylsulfoxide) solution and then add enough seawater to make the volume $5 \mathrm{ml}$. Varying concentrations $(800,500,300,100 \mu \mathrm{g} / \mathrm{ml})$ of samples were obtained by using serial dilution method by adding simulated seawater. Then these solutions were taken in individual test tube where each tube containing $5 \mathrm{ml}$ seawater and 10 brine shrimp nauplii. The test tubes were then observed for $24 \mathrm{~h}$ \& survivors are counted by using a magnifying glass $[37,38]$. The data are processed in a simple program (Microsoft Excel 2007) to estimate $\mathrm{LC}_{50}$ values. Ampicillin trihydrate solution was used as positive control.

\section{Statistical analysis}

All results are expressed as mean \pm standard error of mean (SEM). All statistical analyses were performed by one-way ANOVA Dunnett's $t$-test where ${ }^{*} P<0.05$ was regarded as statistically significant. In addition, all data were analyzed using SPSS software (Version: 20, IBM Corporation, New York, USA). $\mathrm{LC}_{50}$ values were estimated by linear regression equations through the usage of Microsoft Excel 2007 (Microsoft, Redmond, Washington, USA).

\section{Results}

\section{Plant extraction}

The $\%$ yield of the leave extract was $6.06 \mathrm{w} / \mathrm{w}$ dry matter and dark in color.

\section{Phytochemical study}

The preliminary phytochemical studies carried out on different extracts of $A$. solanacea leaf revealed the presence of different phyto-constituents which are presented in Table 1. 


\section{Evaluation of anxiolytic activity Elevated plus maze}

Among all fractions employed during this test, chloroform soluble fraction produced a significant $(p<0.05)$ increase in the time spent in the open arms as well as the number of entries in the open arm of the elevated plus maze respectively as compared to control, indicating the anxiolytic activity but other test samples produced almost opposite of this result. The administration of diazepam $(1.0 \mathrm{mg} / \mathrm{kg}$ body weight) significantly $(p<$ $0.05)$ increased the number of entries as well as the duration of stay in the open arms, as compared to the extract treated groups (Table 2).

\section{Hole-board test method}

In Hole-board test, the chloroform soluble fraction at 200 and $400 \mathrm{mg} / \mathrm{kg}$ body weight was exhibited a significant increase $(p<0.05)$ in head dipping, signifying the anxiolytic activity. The other test samples did not cause any significant change rather number of head dipping decreased as compared to control indicating these fractions might have sedative effect. Diazepam $(1.0 \mathrm{mg} / \mathrm{kg}$ body weight) significantly increased $(p<0.05)$ the number of head dipping (Table 3). The head dipping associated with chloroform soluble fractions remain above the standard diazepam indicating most significant $(p<0.05)$ anxiolytic effect.

\section{Evaluation of sedative activity Open-field test}

During Open field test, as time passed on, the number of squares visited by the mice of the different test groups decreased over time for an interval of $2 \mathrm{~h}$ (Table 4). It was seen that the methanolic extract of $A$. solanacea and its chloroform soluble fraction showed the lower number of squares visited by the mice over time, compared to the control, indicating plant extract might have potential of sedative effect.

\section{Hole cross test}

In the hole cross test, the number of times taken by the mice to cross between the chambers decreased gradually as time passed on for a period of $2 \mathrm{~h}$ (Table 5). For all the groups, the numbers of crossing between the chambers were higher in the pre-treatment period. The methanolic extract and n-hexane soluble fraction showed significant $(p<0.05)$ sedative effect in comparison to other test samples.

Table 1 Presence of Phytochemicals in A. solanacea leaf extract

\begin{tabular}{|c|c|c|c|c|}
\hline Phytochemicals & Test & ASME & ASNH & ASCF \\
\hline \multirow[t]{4}{*}{ Alkaloids } & Dragendorff's test & ++ & + & + \\
\hline & Mayer's test & + & ++ & + \\
\hline & Hager's test & + & + & + \\
\hline & Wagner's test & + & + & + \\
\hline Tannins & $\mathrm{FeCl}_{3}$ test & ++ & - & + \\
\hline \multirow[t]{2}{*}{ Steroids } & Salkowski's test & + & - & + \\
\hline & Liebermann-Burchard test & + & - & + \\
\hline \multirow[t]{2}{*}{ Flavonoids } & $\mathrm{Zn}-\mathrm{HCl}$ reduction test & ++ & + & ++ \\
\hline & Lead acetate test & + & - & + \\
\hline \multirow[t]{2}{*}{ Saponins } & Shake or foam test or froth test. & ++ & ++ & ++ \\
\hline & Olive oil test & + & ++ & + \\
\hline Resins & Test with acetone solution & ++ & + & ++ \\
\hline Glycosides & $\mathrm{NaOH}$ test & ++ & + & + \\
\hline Cardiac-glycosides & Keller- killiani test & + & - & - \\
\hline Anthraquinones glycosides & Hydroxy anthraquinones & - & - & - \\
\hline Carbohydrate & Fehling's test & ++ & + & + \\
\hline Protein & Molisch's test & + & + & + \\
\hline Fats or fixed oils & Biuret test & ++ & + & - \\
\hline Phenols & $\begin{array}{l}\text { Test with } 1 \% \text { of copper } \\
\text { sulphate solution and } \mathrm{NaOH}\end{array}$ & + & + & + \\
\hline \multirow[t]{2}{*}{ Triterpenes } & Salkowski's test & + & - & - \\
\hline & Liebermann-Burchard test & + & - & - \\
\hline
\end{tabular}

Note: $\mathrm{ASME}=$ methanolic extract of $A$. solanacea, $\mathrm{ASCF}=$ Chloroform soluble fraction, $\mathrm{ASNH}=\mathrm{n}$-hexane soluble fraction. Bioavailability key: $(++)$ ve $=$ High presence, $(+)$ ve $=$ Medium presence, $(-)$ ve = Absence 
Table 2 Effect of methanolic extract of Ardisia solanacea on EPM test apparatus while test session

\begin{tabular}{lllll}
\hline Test Groups & $\begin{array}{l}\text { Time spent in open arm } \\
(\text { Sec }) \\
(\text { Mean } \pm \text { SEM) }\end{array}$ & $\begin{array}{l}\text { Number entries into Open } \\
\text { arm } \\
(\text { Mean } \pm \text { SEM) }\end{array}$ & $\begin{array}{l}\text { Time spent in closed arm } \\
(\text { Sec) } \\
(\text { Mean } \pm \text { SEM) }\end{array}$ & $\begin{array}{l}\text { Number entries into closed } \\
\text { arm } \\
(\text { Mean } \pm \text { SEM) }\end{array}$ \\
\hline Control & $60.00 \pm 3.35$ & $7.00 \pm 0.55$ & $240.00 \pm 3.35$ & $18.00 \pm 1.09$ \\
Diazepam & $230.00 \pm 5.04^{\mathrm{a}}$ & $18 \pm 1.30^{\mathrm{a}}$ & $70.00 \pm 3.89^{\mathrm{a}}$ & $8.00 \pm 1.30^{\mathrm{a}}$ \\
(Standard) & & & $273.00 \pm 2.16^{\mathrm{a}}$ & $12.83 \pm 1.30^{\mathrm{a}}$ \\
ASME 200 & $25.34 \pm 0.88^{\mathrm{a}}$ & $4.34 \pm 0.42$ & $277.00 \pm 1.04$ & $16.20 \pm 0.37^{\mathrm{a}}$ \\
ASME 400 & $23.00 \pm 1.05^{\mathrm{a}}$ & $3.40 \pm 0.25^{\mathrm{a}}$ & $275.25 \pm 4.76^{\mathrm{a}}$ & $12.75 \pm 0.85^{\mathrm{a}}$ \\
ASNH 200 & $24.75 \pm 4.76^{\mathrm{a}}$ & $4.25 \pm 0.63$ & $281.80 \pm 1.36^{\mathrm{a}}$ & $5.2 \pm 0.58^{\mathrm{a}}$ \\
ASNH 400 & $18.20 \pm 1.36^{\mathrm{a}}$ & $4.60 \pm 1.36$ & $28.60 \pm 2.29^{\mathrm{a}}$ & $5.80 \pm 0.58^{\mathrm{a}}$ \\
ASCF 200 & $271.40 \pm 2.29^{\mathrm{a}}$ & $11.60 \pm 0.51^{\mathrm{a}}$ & $21.80 \pm 1.39^{\mathrm{a}}$ & $4.20 \pm 0.37^{\mathrm{a}}$ \\
ASCF 400 & $278.20 \pm 1.39^{\mathrm{a}}$ & $15.00 \pm 0.70^{\mathrm{a}}$ & $190.00 \pm 1.52$ & $21.20 \pm 1.02^{\mathrm{a}}$ \\
ASCC 200 & $66.20 \pm 1.77$ & $7.00 \pm 0.70$ & $236.40 \pm 1.36^{\mathrm{a}}$ & $23.60 \pm 0.93$ \\
ASCC 400 & $43.40 \pm 1.21^{\mathrm{a}}$ & $6.00 \pm 1.58$ &
\end{tabular}

Note: Each value represents the mean \pm SEM. $(n=5)$. One- way ANOVA followed by Dunnett's $t$ test. * $p<0.05$, \#\#p $<0.005$ compared with control. Where "a" represents the test was significant. ASME $=$ Methanolic Extract of Ardisia solanacea, $\mathrm{ASNH}=\mathrm{n}$-hexane soluble fraction, $\mathrm{ASCF}=\mathrm{Chloroform}$ soluble fraction, $\mathrm{ASCC}=$ Carbon-tetrachloride soluble fraction

\section{Evaluation of peripheral analgesic effect Acetic acid writhing method}

The crude methanolic extract and chloroform soluble fraction has induced a significant $(p<0.05)$ decrease in the number of writhes that are almost same to that of the standard drug diclofenac sodium (Table 6 and 7).

\section{Evaluation of central analgesic activity Tail immersion test}

In tail immersion method, the methanolic extract and chloroform soluble fraction induced a significant $(p<$ $0.05)$ increased in percent elongation of latency time which is higher than that of the standard diclofenac sodium (Table 8), reaction time (Table 9) and percentage

Table 3 Effect of Ardisia solanacea leaves extract on Hole-board test apparatus while test session

\begin{tabular}{ll}
\hline Test groups & Number of head dipping (Mean \pm SEM) \\
\hline Control & $24.80 \pm 2.05$ \\
Standard & $45.80 \pm 1.72$ \\
ASME 200 & $23.40 \pm 1.03$ \\
ASME 400 & $20.00 \pm 0.70$ \\
ASNH 200 & $27.80 \pm 1.16$ \\
ASNH 400 & $24.40 \pm 1.02$ \\
ASCF 200 & $52.80 \pm 1.43^{\# \#}$ \\
ASCF 400 & $56.20 \pm 1.15^{\# \#}$ \\
ASCC 200 & $26.40 \pm 1.07$ \\
ASCC 400 & $24.00 \pm 1.87$
\end{tabular}

Note: Each value represents the mean \pm SEM. $(n=5)$. One- way ANOVA followed by Dunnett's t test. \#\# $p<0.005$, compared with control. ASME = methanolic Extract of $A$. solanacea, $\mathrm{ASNH}=\mathrm{n}$-hexane soluble fraction, $\mathrm{ASCF}=$ chloroform soluble fraction, $\mathrm{ASCC}=$ carbon tetrachloride soluble fraction of maximum possible effect (Table 9). These extracts possess potential analgesic effect.

\section{Evaluation Oral hypoglycemic activity}

After 30 min of glucose load, the blood glucose level remarkably increased as compared to control. Both, methanolic extract and n-hexane fraction showed reduction in blood glucose level at $90 \mathrm{~min}$ when compared to 30min glucose load (Table 10). For the first session of the experimental period, $30 \mathrm{~min}$ after glucose load these extracts exhibited prominent anti-hyperglycemic activity. In case of methanolic extract was close to that of the standard. The activity was found as sustainable and significant.

Evaluation of cytotoxicity by brine shrimp lethality test The lethal concentration $\left(\mathrm{LC}_{50}\right)$ of the test samples after $24 \mathrm{~h}$ was obtained by a plot of percentage of the shrimps killed against the logarithm of the sample concentration and the best-fit line was obtained from the curve data by means of regression analysis (Table 11). The positive control, compared with the negative control (seawater) was lethal with $\mathrm{LC}_{50}$ value $3.14 \mu \mathrm{g} / \mathrm{ml}$ has given significant mortality to the shrimp (Table 11 ). The $\mathrm{LC}_{50}$ values of the methanolic extract, petroleum ether, chloroform, carbon tetrachloride, and $\mathrm{n}$ hexane soluble fraction of the methanolic extract of $A$. solanacea were found as $5.39 \mu \mathrm{g} / \mathrm{ml}, \quad 5.60 \mu \mathrm{g} / \mathrm{ml}, \quad 16.16 \mu \mathrm{g} / \mathrm{ml}, \quad 3.30 \mu \mathrm{g} / \mathrm{ml}$ and $24.00 \mu \mathrm{g} / \mathrm{ml}$ respectively (Table 11 ).

\section{Discussion}

In this study, we have tested $A$. solanacea leaf extract for CNS, analgesic, oral hypoglycemic and cytotoxicity activity. EPM is an in vivo method for analyzing the potentiality of anxiolytic action. In 
Table 4 Effect of methanolic extract of A. solanacea on Open-field test apparatus while test session

\begin{tabular}{|c|c|c|c|c|c|}
\hline \multirow{2}{*}{$\begin{array}{l}\text { Test } \\
\text { groups }\end{array}$} & \multicolumn{5}{|c|}{ Number of squares visited (Mean \pm SEM) } \\
\hline & $0 \mathrm{~min}$ & $30 \mathrm{~min}$ & $60 \mathrm{~min}$ & $90 \mathrm{~min}$ & $120 \min$ \\
\hline Control & $85.2 \pm 0.58$ & $75.0 \pm 0.70$ & $71.2 \pm 1.16$ & $68 \pm 0.701$ & $62 \pm 0.70$ \\
\hline Standard & $77.0 \pm 0.70^{\# \#}$ & $39.6 \pm 0.51^{\# \#}$ & $23.8 \pm 0.86^{\# \#}$ & $16 \pm 0.70^{\# \#}$ & $10 \pm 0.701^{\# \#}$ \\
\hline ASME 200 & $84.6 \pm 0.51$ & $51.0 \pm 0.70^{\# \#}$ & $32.2 \pm 1.07^{\# \#}$ & $26 \pm 0.70^{\# \#}$ & $22 \pm 0.701^{\# \#}$ \\
\hline ASME 400 & $83.2 \pm 0.86$ & $45.6 \pm 1.03^{\# \#}$ & $29.0 \pm 0.70^{\# \#}$ & $21.2 \pm 0.80^{\# \#}$ & $18.8 \pm 0.66^{\# \#}$ \\
\hline ASNH 200 & $87.6 \pm 1.03$ & $59.2 \pm 1.07^{* * *}$ & $39.6 \pm 1.28^{\# \#}$ & $32 \pm 1.23^{\# \#}$ & $27.6 \pm 1.07^{\# \#}$ \\
\hline ASNH 400 & $84.6 \pm 0.68$ & $54.8 \pm 0.86^{\# \#}$ & $34.8 \pm 0.74^{\# \#}$ & $26.8 \pm 0.86^{\# \#}$ & $25.8 \pm 0.86^{\# \#}$ \\
\hline ASCF 200 & $80.6 \pm 0.50^{*}$ & $45.4 \pm 0.93^{\# \#}$ & $30.6 \pm 0.93^{\# \#}$ & $25 \pm 0.70^{\# \#}$ & $22.6 \pm 0.51^{\# \#}$ \\
\hline ASCF 400 & $83 \pm 1.00$ & $44 \pm 1.14^{\# \#}$ & $26.6 \pm 0.51^{\# \#}$ & $21 \pm 0.70^{\# \#}$ & $19.4 \pm 0.50^{\# \#}$ \\
\hline ASCC 200 & $83.8 \pm 1.07$ & $50 \pm 0.70^{\# \#}$ & $38.2 \pm 1.16^{\# \#}$ & $32.4 \pm 0.75^{\# \#}$ & $28.4 \pm 0.75^{\# \#}$ \\
\hline ASCC 400 & $81.8 \pm 1.90$ & $44 \pm 1.73^{\# \#}$ & $34.2 \pm 0.58^{\# \#}$ & $28 \pm 1^{\# \#}$ & $26 \pm 0.84^{\# \#}$ \\
\hline
\end{tabular}

Note: Each value represents the mean \pm SEM. $(n=5)$. One- way ANOVA followed by Dunnett's $t$ test. \#\#p $<0.005,{ }^{*} p<0.05$ compared with control. ASME $=$ methanolic Extract of $A$. solanacea, $\mathrm{ASNH}=\mathrm{n}$-hexane soluble fraction, $\mathrm{ASCF}=$ chloroform soluble fraction, $\mathrm{ASCC}=$ carbon tetrachloride soluble fraction

which, experimental animals usually prefer covered areas of the maze and might have a desire for segment enclosed by protecting wall assumed to be aversive [39]. If animals which are treated with experimental plant extracts exhibited any significant changes in open arms statistically considered as the evidence of anxiolytic effectiveness of these given plant extracts. Among other fractions, chloroform soluble fraction at both doses level of $200 \mathrm{mg} / \mathrm{kg}$ and $400 \mathrm{mg} / \mathrm{kg}$ which was indicated with increased time spent and entries in open arms and decreased time spent and entries in closed arms. The anxiolytic effect of this fraction is as like as diazepam molecule which is considered as popular drug of benzodiazepine. In central system, GABA is known as a major neurochemical. They could act by potentiating the GABAergic inhibition in the CNS system through hyperpolarization, which can result in a firing rate of vital neurons within the brain, or it may also be act by directly activating GABA receptors [40]. Several studies have implied that plants containing tannins, saponins and flavonoids may possess an effect on several multiple CNS disorders [41]. Preliminary phytochemical investigations and plant extract suggest that several neuroactive steroids and flavonoids are ligands for GABA receptors in the CNS; which suggest that they can act like benzodiazepine-like molecule [40]. Another way to view anxiolytic activity is hole board test. Head-dipping behavior of experimental animals is the main basis of hole board apparatus. If the test animals are sensitive to changes in the emotional state and or in anxiolytic state, head-dipping might have increased [42, 43]. Increased head-dipping was observed with chloroform soluble fraction (at both doses level of $200 \mathrm{mg} / \mathrm{kg}$ and $400 \mathrm{mg} / \mathrm{kg}$ ) in respect to other fractions. Another

Table 5 Effect of methanolic extract of Ardisia solanacea on Hole-crossed test apparatus while test session

\begin{tabular}{|c|c|c|c|c|c|}
\hline \multirow{2}{*}{$\begin{array}{l}\text { Test } \\
\text { groups }\end{array}$} & \multicolumn{5}{|c|}{ Number of hole crossed (Mean \pm SEM) } \\
\hline & $0 \mathrm{~min}$ & $30 \mathrm{~min}$ & $60 \mathrm{~min}$ & $90 \mathrm{~min}$ & $120 \mathrm{~min}$ \\
\hline Control & $20 \pm 0.70$ & $19.2 \pm 1.74$ & $18.4 \pm 1.54$ & $18.2 \pm 1.39$ & $15.2 \pm 0.58$ \\
\hline Standard & $19 \pm 0.71$ & $8.4 \pm 1.37^{\# \#}$ & $5.8 \pm 0.74^{\# \#}$ & $4.4 \pm 0.93^{\# \#}$ & $3.2 \pm 0.58^{\# \#}$ \\
\hline ASME 200 & $20.8 \pm 0.58$ & $10.4 \pm 0.68^{\# \#}$ & $7.8 \pm 0.37^{\# \#}$ & $5.2 \pm 0.58^{\# \#}$ & $3.4 \pm 0.68^{\# \#}$ \\
\hline ASME 400 & $21.8 \pm 0.86$ & $9.8 \pm 0.74^{\# \#}$ & $7.6 \pm 0.40^{\# \#}$ & $4.6 \pm 0.40^{\# \#}$ & $3.2 \pm 0.49^{\# \#}$ \\
\hline ASNH 200 & $21.2 \pm 1.02$ & $13.4 \pm 0.51^{\# \#}$ & $9.80 \pm 0.74^{\# \#}$ & $7.2 \pm 0.37^{\# \#}$ & $4.6 \pm 0.51^{\# \#}$ \\
\hline ASNH 400 & $23.4 \pm 0.93$ & $11.4 \pm 0.51^{\# \#}$ & $7.6 \pm 0.51^{\# \#}$ & $5.8 \pm 0.37^{\# \#}$ & $4.2 \pm 0.58^{\# \#}$ \\
\hline ASCF 200 & $20.6 \pm 0.93$ & $10.2 \pm 0.80^{\# \#}$ & $7.2 \pm 0.37^{\# \#}$ & $5 \pm 0.55^{\# \#}$ & $3.2 \pm 0.66^{\# \#}$ \\
\hline ASCF 400 & $22.6 \pm 1.75$ & $10.2 \pm 1.16^{\# \#}$ & $7.6 \pm 1.55^{\# \#}$ & $4.8 \pm 1.12^{\# \#}$ & $3.2 \pm 1.02^{\# \#}$ \\
\hline ASCC 200 & $24.2 \pm 1.77$ & $21.8 \pm 1.59$ & $21.4 \pm 1.47$ & $22.2 \pm 1.36$ & $20.6 \pm 1.83^{*}$ \\
\hline ASCC 400 & $22.8 \pm 1.96$ & $20.6 \pm 2.12$ & $18.4 \pm 1.64$ & $17.2 \pm 1.63$ & $16.4 \pm 1.20$ \\
\hline
\end{tabular}

Note: Each value represents the mean \pm SEM. $(n=5)$. One- way ANOVA followed by Dunnett's t test. ${ }^{\# \#} p<0.005,{ }^{*} \mathrm{p}<0.05$ compared with control. ASME $=$ Methanolic Extract of $A$. solanacea, ASNH $=\mathrm{n}$-hexane soluble fraction, ASCF $=$ Chloroform soluble fraction, $\mathrm{ASCC}=\mathrm{Carbon}$-tetrachloride soluble fraction 
Table 6 Evaluation of analgesic activity of Ardisia solanacea by counting the number of writhing after the intraperitoneal administration of $0.7 \%$ acetic acid

\begin{tabular}{llll}
\hline Animal Group & Mean & \% of Writhing & \% of inhibition \\
\hline Control & 56.6 & - & - \\
Standard & 14.8 & 26.15 & 73.85 \\
ASME 200 & 21.6 & 38.16 & 61.84 \\
ASME 400 & 19.2 & 33.93 & 66.07 \\
ASNH 200 & 42.4 & 74.92 & 25.08 \\
ASNH 400 & 38.4 & 67.85 & 32.15 \\
ASCF 200 & 23.0 & 40.64 & 59.36 \\
ASCF 400 & 19.0 & 33.57 & 66.43
\end{tabular}

Note: $\mathrm{ASME}=$ Methanolic extract of Ardisia solanacea, $\mathrm{ASNH}=\mathrm{n}$-hexane soluble fraction, $\mathrm{ASCF}=$ chloroform soluble fraction. $\mathrm{ASME}=$ methanolic extract of Ardisia A. solanacea, $\mathrm{ASCF}=$ Chloroform soluble fraction, $\mathrm{ASNH}=\mathrm{n}$-hexane soluble fraction

vital step in evaluating the action of drug on CNS is to inspect its effect on locomotor activity of testing animal. Locomotor activity is a motive to act on CNS by uplifting alertness and decreasing the motion activity could induce a sedative action [44]. Level of CNS excitement can be evaluated from locomotor activity and reduction of this activity is closely related to sedation turn out from the CNS depression [45]. Here, hole cross and open filed tests were used to observe this activity. In respect to other fractions, chloroform soluble fraction and methanolic extract of $A$. solanacea leaves decrease the number of hole crossed and the number of square blocks from 1st (30 $\mathrm{min}$ ) observation to final observation (120 $\mathrm{min})$ and afterward influenced the locomotor activity in mices which exhibits the sedative activity. Acetic acid induce test is wellused for assessing the peripheral analgesic activity [46]. Acetic acid induces pain by enhancing the PG2 and PG2 $\alpha$ at the receptor sites of the organ cavity which means that carboxylic acid acts indirectly by increasing the discharge of endogenous mediators [47, 48]. Acetic acid produces writhing reflex in experimental animal by chemo-sensitive nociceptor [49]. Non-steroidal anti-inflammatory drugs
Table 8 Percent elongation of latency time after administration of all test samples

\begin{tabular}{|c|c|c|c|c|c|}
\hline \multirow{2}{*}{$\begin{array}{l}\text { Test } \\
\text { samples }\end{array}$} & \multirow{2}{*}{$\begin{array}{l}\text { Dose } \\
\text { (mg/ } \\
\mathrm{kg})\end{array}$} & \multicolumn{4}{|c|}{$\%$ elongation of latency time } \\
\hline & & $30 \mathrm{~min}$ & $60 \mathrm{~min}$ & $90 \mathrm{~min}$ & $120 \mathrm{~min}$ \\
\hline Standard & 50 & $53.57 \%$ & $72.97 \%$ & $70.45 \%$ & $65.12 \%$ \\
\hline ASME 200 & 200 & $38.09 \%$ & $67.74 \%$ & $65.79 \%$ & $61.54 \%$ \\
\hline ASME 400 & 400 & $50.00 \%$ & $72.23 \%$ & $69.77 \%$ & $63.42 \%$ \\
\hline ASNH 200 & 200 & $27.78 \%$ & $54.55 \%$ & $55.17 \%$ & $55.88 \%$ \\
\hline ASNH 400 & 400 & $22.23 \%$ & $62.96 \%$ & $59.37 \%$ & $59.46 \%$ \\
\hline ASCF 200 & 200 & $50.00 \%$ & $72.23 \%$ & $68.29 \%$ & $65.90 \%$ \\
\hline ASCF 400 & 400 & $50.00 \%$ & $76.19 \%$ & $72.34 \%$ & $67.39 \%$ \\
\hline
\end{tabular}

ASME = methanolic extract of $A$. solanacea, $\mathrm{ASCF}=$ Chloroform soluble fraction, $\mathrm{ASNH}=\mathrm{n}$-hexane soluble fraction

act by blocking this stimulation of sensory neurons in response to inflammatory mediators [50]. Moreover, the level of analgesia can also be noted by the percent reduction in the number of abdominal squirms or cramps [51]. The standard drug, methanolic extract and its chloroform soluble fraction (at both doses level of $200 \mathrm{mg} / \mathrm{kg}$ and $400 \mathrm{mg} / \mathrm{kg}$ ) significantly decreased the mean number of writhes. Subsequently, increase in the percent inhibition of abdominal squirms. The effect was closely related to that of standard diclofenac sodium. Tail immersion test is based on observation that morphine-like drugs selectively enhances reaction time of typical tail withdrawal reflex in mices. The level of analgesia of extract is indicated by the increased in basal latency period [52, 53]. Both the methanolic extract and its chloroform soluble fraction (at $200 \mathrm{mg} / \mathrm{kg}$ and $400 \mathrm{mg} / \mathrm{kg}$ ) increase the reaction time, basal latency and \% MPE than other fraction. The effect was found nearly stable from $30 \mathrm{~min}$ to $120 \mathrm{~min}$. The basal latency was increased by the extracts indicates that they may act via centrally mediated analgesic mechanism [53]. In this model, sensory nerves sensitize the nociceptors and the involvement of endogenous substances such

Table 7 Effect of Ardisia solanacea leaves extract during acetic acid writhing test session

\begin{tabular}{lll}
\hline Animal Group & Number of writhing (Mean \pm SEM) & \% of inhibition of writhing \\
\hline Control & $56.6 \pm 2.67$ & $73.85 \%$ \\
Standard & $14.8 \pm 1.16^{\# \#}$ & $61.84 \%$ \\
ASME 200 & $21.6 \pm 3.53^{\# \#}$ & $66.07 \%$ \\
ASME 400 & $19.2 \pm 1.83^{\# \#}$ & $25.08 \%$ \\
ASNH 200 & $42.4 \pm 3.50^{\#}$ & $32.15 \%$ \\
ASNH 400 & $38.4 \pm 1.03^{\# \#}$ & $59.36 \%$ \\
ASCF 200 & $23.0 \pm 1.48^{\# \#}$ & $66.43 \%$
\end{tabular}

Note: Each value represents the mean \pm SEM. $(\mathrm{n}=5)$. One- way ANOVA followed by Dunnett's $\mathrm{t}$ test. ${ }^{\# \#} \mathrm{p}<0.005, \# p<0.01$ compared with control. ASME $=$ methanolic extract of $A$. solanacea, $\mathrm{ASCF}=$ Chloroform soluble fraction, $\mathrm{ASNH}=\mathrm{n}$-hexane soluble fraction 
Table 9 Effects of methanolic extracts of different plant parts of A. solanacea on Tail Immersion Test in mice

\begin{tabular}{|c|c|c|c|c|c|c|}
\hline \multirow{2}{*}{$\begin{array}{l}\text { Test } \\
\text { samples }\end{array}$} & \multirow[t]{2}{*}{ Dose $(\mathrm{mg} / \mathrm{kg})$} & \multicolumn{5}{|c|}{ Reaction times in seconds (Mean \pm SEM) and $\% \mathrm{MPE}$} \\
\hline & & Pre-treatment & $30 \mathrm{~min}$ & $60 \mathrm{~min}$ & $90 \mathrm{~min}$ & $120 \mathrm{~min}$ \\
\hline Control & $0.25 \mathrm{ml} / 25 \mathrm{~g}$ b.w & $2.8 \pm 0.37$ & $\begin{array}{l}2.6 \pm 0.24 \\
(1.64 \%)\end{array}$ & $\begin{array}{l}2 \pm 0.32 \\
(6.56 \%)\end{array}$ & $\begin{array}{l}2.6 \pm 0.24 \\
(1.64 \%)\end{array}$ & $\begin{array}{l}3 \pm 0.32 \\
(1.63 \%)\end{array}$ \\
\hline Standard & 50 & $2.6 \pm 0.40$ & $\begin{array}{l}5.6 \pm 0.25^{\# \#} \\
(24.41 \%)\end{array}$ & $\begin{array}{l}7.4 \pm 0.24^{\# \#} \\
(38.70 \%)\end{array}$ & $\begin{array}{l}8.8 \pm 0.37^{* * *} \\
(50.00 \%)\end{array}$ & $\begin{array}{l}8.6 \pm 0.40^{\# \#} \\
(48.38 \%)\end{array}$ \\
\hline ASME 200 & 200 & $2.4 \pm 0.25$ & $\begin{array}{l}4.2 \pm 0.37^{*} \\
(14.28 \%)\end{array}$ & $\begin{array}{l}6.2 \pm 0.37^{\# \#} \\
(30.16 \%)\end{array}$ & $\begin{array}{l}7.6 \pm 0.40^{* * *} \\
(41.27 \%)\end{array}$ & $\begin{array}{l}7.8 \pm 0.37^{\# \#} \\
(42.85 \%)\end{array}$ \\
\hline ASME 400 & 400 & $2.6 \pm 0.40$ & $\begin{array}{l}5.2 \pm 0.37^{\# \#} \\
(20.97 \%)\end{array}$ & $\begin{array}{l}7.2 \pm 0.37^{\# \#} \\
(37.09 \%)\end{array}$ & $\begin{array}{l}8.6 \pm 0.24^{* * * *} \\
(48.38 \%)\end{array}$ & $\begin{array}{l}8.2 \pm 0.20^{\# \#} \\
(45.16 \%)\end{array}$ \\
\hline ASNH 200 & 200 & $2.8 \pm 0.37$ & $\begin{array}{l}3.6 \pm 0.25 \\
(6.55 \%)\end{array}$ & $\begin{array}{l}4.4 \pm 0.24^{\# \#} \\
(13.12 \%)\end{array}$ & $\begin{array}{l}5.8 \pm 0.37^{* *} \\
(24.59 \%)\end{array}$ & $\begin{array}{l}6.8 \pm 0.37^{\# \#} \\
(32.78 \%)\end{array}$ \\
\hline ASNH 400 & 400 & $2.2 \pm 0.20$ & $\begin{array}{l}3.4 \pm 0.24 \\
(9.37 \%)\end{array}$ & $\begin{array}{l}5.4 \pm 0.25^{\# \#} \\
(25.00 \%)\end{array}$ & $\begin{array}{l}6.4 \pm 0.24^{* * *} \\
(32.81 \%)\end{array}$ & $\begin{array}{l}7.4 \pm 0.25^{\# \#} \\
(40.63 \%)\end{array}$ \\
\hline ASCF 200 & 200 & $2 \pm 0.00$ & $\begin{array}{l}5.2 \pm 0.20^{\# \#} \\
(24.62 \%\end{array}$ & $\begin{array}{l}7.2 \pm 0.20^{\# \#} \\
(40.00 \%)\end{array}$ & $\begin{array}{l}8.2 \pm 0.20^{* * *} \\
(47.69 \%)\end{array}$ & $\begin{array}{l}8.8 \pm 0.37^{\# \#} \\
(52.30 \%)\end{array}$ \\
\hline ASCF 400 & 400 & $2.2 \pm 0.20$ & $\begin{array}{l}5.2 \pm 0.20^{* * *} \\
(23.44 \%)\end{array}$ & $\begin{array}{l}8.4 \pm 0.25^{* * *} \\
(48.44 \%)\end{array}$ & $\begin{array}{l}9.4 \pm 0.24^{* * *} \\
(56.25 \%)\end{array}$ & $\begin{array}{l}9.2 \pm 0.20^{* * *} \\
(54.68 \%)\end{array}$ \\
\hline
\end{tabular}

Note: Each value represents the mean \pm SEM. $(n=5)$. One- way ANOVA followed by Dunnett's $t$ test. ${ }^{\# \#} p<0.005,{ }^{*} p<0.05$ compared with control. ASME $=$ methanolic extract of $A$. solanacea, $\mathrm{ASCF}=$ Chloroform soluble fraction, $\mathrm{ASNH}=\mathrm{n}$-hexane soluble fraction

as prostaglandins are minimized [54]. The methanolic extract of A. solanacea revealed the presence of phytochemicals such as alkaloids, tannins and flavonoid, which may be major contributors to this activity [55]. The hypoglycemic property of plant sample was confirmed by enhanced glucose tolerance in diabetic or normoglycaemic treated mices indicating that any plant samples have the capacity to correct impaired glucose tolerance in diabetes, hence, exhibit antidiabetic activity [56]. In this experiment, methanolic extract and n-hexane soluble fraction (at the dose level of $200 \mathrm{mg} / \mathrm{kg}$ ) exhibited significant hypoglycemia by reducing orally administered glucose level. A similar report has confirmed from the event of Syzygium aromaticum extract in streptozotocin-induced diabetic mices following an oral glucose tolerance test [57]. Differing degree of lethality to Artemia salina was observed with exposure to different dose levels of the test samples. Among the test samples, reasonable cytotoxicity was observed with methanolic extract and its pet-ether and carbon tetrachloride fractions at least $\mathrm{LC}_{50}$ values. Flavonoids show anti-allergic, anticancer, anti-inflammatory and antimicrobial activities. Tannins, which are present in this plant may contain significant cytotoxic and antitumor potency [57]. In the future, we will find out which components are exactly responsible for those activities by performing compound identification technique such as chromatographic analysis.

\section{Conclusion}

These studies discover some pharmacological potential that can be beneficial for modern medical science to develop medical science to discover drugs from

Table 10 Oral Hypoglycaemic activity of methanolic extract of $A$. solanacea and its $n$-hexane soluble fraction

\begin{tabular}{|c|c|c|c|c|c|}
\hline \multirow[t]{2}{*}{ Animal group } & \multirow{2}{*}{$\begin{array}{l}\text { Dose } \\
\mathrm{Mg} / \\
\mathrm{kg}\end{array}$} & \multicolumn{4}{|l|}{ Mean \pm SEM } \\
\hline & & O Minute & 30 Minute & 90 Minute & 120 Minute \\
\hline $\begin{array}{l}\text { Control } \\
\text { (Normal Saline) }\end{array}$ & & $6.64 \pm 0.44$ & $\begin{array}{l}14.08 \pm 0.12 \\
(+112.05)^{a}\end{array}$ & $\begin{array}{l}8.98 \pm 0.89 \\
(-36.22)^{b}\end{array}$ & $\begin{array}{l}6.76 \pm 0.33 \\
(-52)^{b}\end{array}$ \\
\hline Standard (Glibenclamide) & 10 & $5.82 \pm 0.32$ & $\begin{array}{l}10.06 \pm 0.73^{*} \\
(+72.85)^{\mathrm{a}}\end{array}$ & $\begin{array}{l}4.6 \pm 0.20^{\# \#} \\
(-54.27)^{b}\end{array}$ & $\begin{array}{l}4.18 \pm 0.24^{\# \#} \\
(-58.45)^{\mathrm{b}}\end{array}$ \\
\hline ASME & 200 & $6.42 \pm 0.31$ & $\begin{array}{l}10.16 \pm 0.37^{*} \\
(+58.25)^{\mathrm{a}}\end{array}$ & $\begin{array}{l}4.68 \pm 0.14^{\# \#} \\
(-53.94)^{b}\end{array}$ & $\begin{array}{l}4.4 \pm 0.10^{\# \#} \\
(-56.69)^{b}\end{array}$ \\
\hline ASNH & 200 & $6.96 \pm 0.24$ & $\begin{array}{l}10.80 \pm 0.33 \\
(+55.17)^{\mathrm{a}}\end{array}$ & $\begin{array}{l}5.6 \pm 0.36^{\#} \\
(-48.15)^{b}\end{array}$ & $\begin{array}{l}4.74 \pm 0.24^{\# \#} \\
(-58.62)^{\mathrm{b}}\end{array}$ \\
\hline
\end{tabular}

Figures in parentheses are the $\%$ increase $(+)$ or decrease $(-)$ glucose level; $a=$ compared to the glucose level at zero time, $b=$ compared to the glucose level at 30 min after the glucose load, ASME = Methanolic extract of $A$. solanacea, ASNH $=n$-hexane soluble fraction. Each value represents the mean \pm SEM. $(n=5)$. Oneway ANOVA followed by Dunnett's $t$ test. \#\#p $<0.005, " p<0.01,{ }^{*} p<0.05$ compared with control 
Table 11 A brief overview of the cytotoxic activity of the different extracts of A. solanaced

\begin{tabular}{llll}
\hline Sample & Equation & $R^{2}$ & $L C_{50}(\mu \mathrm{g} / \mathrm{ml})$ \\
\hline Standard(Ampicillin trihydrate) & $y=29.975 x+35.092$ & $R^{2}=0.3532$ & 3.14 \\
ASME & $y=20.971 x+34.658$ & $R^{2}=0.7212$ & 5.39 \\
ASPE & $y=23.998 x+32.032$ & $R^{2}=0.9444$ & 5.60 \\
ASNH & $y=28.521 x+10.633$ & $R^{2}=0.7723$ & 24.00 \\
ASCH & $y=20.971 x+24.658$ & $R^{2}=0.7212$ & 16.16 \\
ASCT & $y=8.4982 x+71.087$ & $R^{2}=0.4343$ & 3.30 \\
\hline
\end{tabular}

Note: $\mathrm{ASME}=$ methanolic extract of $A$. solanacea, $\mathrm{ASPE}=$ pet ether soluble fraction, $\mathrm{ASNH}=\mathrm{n}$-hexane soluble fraction, $\mathrm{ASCT}=$ carbon tetrachloride soluble fraction, $\mathrm{ASCH}=$ chloroform soluble fraction

plant source with different pharmacological potentiality with the least number of side effects. A. solanacea can be used to treat some neuropharamcological disorders, formulated into oral hypoglycemic agent. This study will help the researcher to uncover the critical areas of biomedical science that many researchers were not able to explore.

\section{Abbreviations}

CNS: Central Nervous System; DMSO: Dimethylsulfoxide; EPM: Elevated Plus Maze; GABA: Gamma Amino Butyric Acid; LC: Lethal Concentrations; MPE: Maximal Possible Effect; PG: Prostaglandins

\section{Acknowledgements}

The authors are grateful to BCSIR and Pharmacy Department of Jahangirnagar University for their generous supply of mice. The authors are also thankful to all the teachers and staffs of the Department of Pharmacy, University of Chittagong for their cordial co-operation by providing laboratory support to carry out the research work.

\section{Authors' contributions}

MKH designed the experiments and conception. MRI conducted the research work. Data interpretation and analysis were aided by JN and NMP. MSH critically reviews the manuscript. SMNU made the necessary corrections in the write up and gave final approval for the submission of revised version. All authors read and approved the final manuscript.

\section{Authors' information}

Mohammad Rashedul Islam, Jannatul Naima and Nawreen Monir Proma are Lecturer of Department of Pharmacy, University of Chittagong. Md. Saddam Hussain is also a Lecturer of Department of Pharmacy, Noakhali Science and Technology University. S. M. Naim Uddin is working as an Assistant Professor at Department of Pharmacy, University of Chittagong. Finally Mohammed Kamrul Hossain is the Professor of Pharmacy Department, University of Chittagong.

\section{Funding}

The research work was partially supported by the Department of Pharmacy, University of Chittagong, Bangladesh. The authors have no other relevant affiliations or financial involvement with any organization.

\section{Availability of data and materials}

All data and materials are contained and described within the manuscript. The data set was deposited in publicly available repositories. The plant's materials for the study were identified and voucher specimens are deposited at Pharmacy Department of University of Chittagong.

\section{Ethics approval and consent to participate}

All authors hereby declare that "Principles of laboratory animal care" (NIH publication No. 85-23, revised 1985) were followed, as well as specific national laws where applicable. All experiments have been examined and approved by the appropriate ethics committee.
Consent for publication

All authors have given their valuable consent to publish this article.

\section{Competing interests}

The authors declare that they have no competing interests.

\section{Author details}

${ }^{1}$ Department of Pharmacy, University of Chittagong, Chittagong 4331, Bangladesh. ${ }^{2}$ Department of Pharmacy, Noakhali Science and Technology University, Noakhali 3814, Bangladesh.

Received: 14 June 2019 Accepted: 10 October 2019

Published online: 29 October 2019

\section{References}

1. Marshall E. Bastions of tradition adapt to alternative medicine. Science. 2000; 288(5471):1571-2

2. Budzinski JW, Foster BC, Vandenhoek S, Arnason JT. An in vitro evaluation of human cytochrome P450 3A4 inhibition by selected commercial herbal extracts and tinctures. Phytomedicine. 2000;7(4):273-82.

3. Ibrahim M, Hussain MS, Sultana F, Abhi N, Ahmed T, Uddin SN, et al. Therapeutic potentiality of Diospyros blancoi Linn. Seeds against pain, Thrombus and inflammation: an in vivo and in vitro study. AJMBR. 2019;12: 36-41.

4. Claquin P. Private health care providers in rural Bangladesh. Social Science and Medicine. Part B: Medical Anthropology. 1981;15(2):153-7.

5. Bhardwaj SM, Paul BK. Medical pluralism and infant mortality in a rural area of Bangladesh. Soc Sci Med. 1986;23(10):1003-10.

6. Hossain MF, Talukder B, Rana MN, Tasnim R, Nipun TS, Uddin SN, Hossen SM. In vivo sedative activity of methanolic extract of Stericulia villosa Roxb. Leaves BMC Complement Altern Med. 2016;16(1):398.

7. Uddin SN, Amin MN, Shahid-Ud-Daula AF, Hossain H, Haque MM, Rahman MS, Kader MA. Phytochemical screening and study of antioxidant and analgesic potentials of ethanolic extract of Stephania japonica Linn. J Med Plants Res. 2014;8(37):1127-33.

8. http://www.efloras.org/florataxon.aspx?flora_id=2\&taxon_id =210000072

9. Nordin ML, Kadir AA, Zakaria ZA, Abdullah R, Abdullah MN. In vitro investigation of cytotoxic and antioxidative activities of Ardisia crispa against breast cancer cell lines, MCF-7 and MDA-MB-231. BMC Complement Altern Med. 2018;18(1):87.

10. Syed E, Mashroor B, Hossain FM, Bi-Illah N, Bhattacharjee R, Hannan JM. Evaluation of phytochemical screening and antimicrobial activities of Ethanolic extracts of leaves and bark of Ardisia colorata. IJPLS. 2013;2(4):15864.

11. Kobayashi H, de Mejía E. The genus Ardisia: a novel source of healthpromoting compounds and phytopharmaceuticals. J Ethnopharmacol. 2005; 96(3):347-54.

12. Phadungkit M, Luanratana O. Anti-Salmonella activity of constituents of Ardisia elliptica Thunb. Nat Prod Res. 2006;20(7):693-6.

13. Moongkarndi P, Kosem N, Luanratana O, Jongsomboonkusol S, Pongpan N. Antiproliferative activity of Thai medicinal plant extracts on human breast adenocarcinoma cell line. Fitoterapia. 2004;75(3-4):375-7.

14. Ezeja M, Omeh Y, Ezeigbo I, Ekechukwu A. Evaluation of the analgesic activity of the methanolic stem bark extract of Dialium guineense (wild). Ann Med Health Sci Res. 2011;1(1):55-62. 
15. Bolanle AO, Funmilola AS, Adedayo A. Proximate analysis, mineral contents, amino acid composition, anti-nutrients and phytochemical screening of Brachystegia eurycoma harms and Pipper Guineense Schum and Thonn. Am J Food Nutr. 2014;2:11-7.

16. Ugbaja CC, Fawibe OO, Oyelakin AS, Fadimu IO, Ajiboye AA, Agboola DA. Comparative phytochemical and nutritional composition of Trichosanthes cucumerina (L.) and some Solanum lycopersicum (L.) cultivars in nigeria. Am J Plant Sci. 2017:8(02):297.

17. Harborne JB. Phytochemical methods chapman and hall. Ltd London. 1973; 4:49-188.

18. Sunanda BP, Latha K, Rammohan B, Uma Maheswari MS, Surapaneni KM. Evaluation of the neuroprotective effects of curcumin (turmeric) against scopolamine induced cognitive impairment in mice. Int J Pharm Phytochem Res. 2014;6:133-6.

19. Pellow S, Chopin P, File SE, Briley M. Validation of open: closed arm entries in an elevated plus-maze as a measure of anxiety in the rat. J Neurosci Methods. 1985;14(3):149-67.

20. Vogel HG, editor. Drug discovery and evaluation: pharmacological assays. Springer Science \& Business Media. 2002.

21. Emamghoreishi M, Khasaki M, Aazam MF. Coriandrum sativum: evaluation of its anxiolytic effect in the elevated plus-maze. J Ethnopharmacol. 2005;96(3): 365-70.

22. Miyakawa T, Yagi T, Kagiyama A, Niki H. Radial maze performance, openfield and elevated plus-maze behaviors in Fyn-kinase deficient mice: further evidence for increased fearfulness. Mol Brain Res. 1996;37(1-2):145-50.

23. File SE, Wardill AG. Validity of head-dipping as a measure of exploration in a modified hole-board. Psychopharmacol. 1975;44(1):53-9.

24. Ljungberg $T$, Ungerstedt $U$. Automatic registration of behaviour related to dopamine and noradrenaline transmission. Eur J Pharmacol. 1976;36(1):1818.

25. Crawley JN. Exploratory behavior models of anxiety in mice. Neurosci Biobehav Rev. 1985;9(1):37-44.

26. Kliethermes $\mathrm{CL}$, Crabbe JC. Pharmacological and genetic influences on holeboard behaviors in mice. Pharmacol Biochem Be. 2006;85(1):57-65.

27. Gupta BD, Dandiya PC, Gupta ML. A psycho-pharmacological analysis of behaviour in rats. Jpn J Pharmacol. 1971;21(3):293-8.

28. Takagi K, Watanabe M, Saito H. Studies of the spontaneous movement of animals by the hole cross test; effect of 2-dimethyl-aminoethanol and its acyl esters on the central nervous system. Jpn J Pharmacol. 1971;21(6):797810.

29. Koster R. Acetic acid for analgesic screening. InFed proc. 1959;18:412.

30. Vogel GH, Vogel WH. Drug discovery and evaluation: pharmacological assays springer-Verlag. Berlin: Germany; 1997.

31. Devi PU, Ganasoundari A, Rao BS, Srinivasan KK. In vivo radioprotection by ocimum flavonoids: survival of mice. Radiat Res. 1999;151(1):74-8.

32. Di Stasi LC, Costa M, Mendaçolli SL, Kirizawa M, Gomes C, Trolin G. Screening in mice of some medicinal plants used for analgesic purposes in the state of Sao Paulo. J Ethnopharmacol. 1988;24(2-3):205-11.

33. Fan SH, Ali NA, Basri DF. Evaluation of analgesic activity of the methanol extract from the galls of Quercus infectoria (Olivier) in rats. Evid Based Complement Alternat Med. 2014;2014.

34. Kumawat RK, Kumar S, Sharma S. Evaluation of analgesic activity of various extracts of Sida tiagii Bhandari. Acta Pol Pharm. 2012;69:1103-9.

35. Joy KL, Kuttan R. Anti-diabetic activity of Picrorrhiza kurroa extract. J Ethnopharmacol. 1999;67(2):143-8.

36. Meyer BN, Ferrigni NR, Putnam JE, Jacobsen LB, Nichols DJ, McLaughlin JL. Brine shrimp: a convenient general bioassay for active plant constituents. Planta Med. 1982;45(5):31-4.

37. Mclaughlin JL, Rogers LL, Anderson JE. The use of biological assays to evaluate botanicals. Drug Inf J. 1998;32(2):513-24.

38. Amin MN, Majumder MS, Moghal MM, Banik S, Kar A, Hossain MM Anthelmintic and cytotoxic activities of two medicinal plants: Polygonum viscosum and Aphanamixis polystachya growing in Bangladesh. J Sci Res. 2014;6(2):339-45

39. Collimore KC, Rector NA. Treatment of anxiety disorders with comorbid depression: a survey of expert CBT clinicians. Cogn Behav Pract. 2014;21(4): 485-93.

40. Verma A, Jana GK, Sen S, Chakraborty R, Sachan S, Mishra A. Pharmacological evaluation of Saraca indica leaves for central nervous system depressant activity in mice. J Pharm Sci Res. 2010;2(6):338-43.
41. Yadav G, Garg VK, Thakur N, Khare P. Locomotor activity of methanolic extract of Saraca indica bark. Adv Biol Res. 2013;7:1-3.

42. Wei XY, Yang JY, Wang JH, Wu CF. Anxiolytic effect of saponins from Panax quinquefolium in mice. J Ethnopharmacol. 2007:111(3):613-8.

43. Foyet HS, Tsala DE, Bouba AA, Hritcu L. Anxiolytic and antidepressant like effects of the aqueous extract of Alafia multiflora stem barks in rodents. Adv Pharmacol Sci. 2012;2012:912041.

44. Bhattacharya SK, Satyan KS. Experimental methods for evaluation of psychotropic agents in rodents: I--anti-anxiety agents. Indian J Exp Biol. 1997;35(6):565-75.

45. Islam NU, Khan I, Rauf A, Muhammad N, Shahid M, Shah MR. Antinociceptive, muscle relaxant and sedative activities of gold nanoparticles generated by methanolic extract of Euphorbia milii. BMC Complement Altern Med. 2015;15:160.

46. Trongsakul S, Panthong A, Kanjanapothi D, Taesotikul T. The analgesic, antipyretic and anti-inflammatory activity of Diospyros variegata Kruz. J Ethnopharmacol. 2003;85(2-3):221-5.

47. Ezeja MI, Omeh YS, Ezeigbo II, Ekechukwu A. Evaluation of the analgesic activity of the methanolic stem bark extract of Dialium guineense (wild). Ann Med Health Sci Res. 2011;1(1):55-62.

48. Lee $\mathrm{KH}$, Choi EM. Analgesic and anti-inflammatory effects of Ligularia fischeri leaves in experimental animals. J Ethnopharmacol. 2008;120(1):103-7.

49. Onasanwo SA, Elegbe RA. Antinociceptive and anti-inflammatory properties of the leaf extract of Hedranthera barteri in rats and mice. Afr J Biomed Res. 2006;2:109-18.

50. Akindele AJ, Ibe IF, Adeyemi OO. Analgesic and antipyretic activities of Drymaria cordata (Linn.) Willd (Caryophyllaceae) extract. Afr J Tradit Complement Altern Med. 2012;9(1):25-35.

51. Machioro M, Blank MFA, Moura RHV, Antioniolli AR. Antinociceptive activity of the aqueous extract of Erythrina velutina leaves. Fitoterapia. 2005;6:63742.

52. Elisabetsky E, Amador TA, Albuquerque RR, Nunes DS. Do CT Carvalho a. analgesic activity of Psychotria colorata (Willd. Ex R. \& S.) Muell. Arg. Alkaloids. J Ethnopharmacol. 1995;48(2):77-83.

53. Pal S, Sen T, Chaudhuri AK. Neuropsychopharmacological profile of the methanolic fraction of Bryophyllum pinnatum leaf extract. J Pharm Pharmacol. 1999:51(3):313-8.

54. Bachhav RS, Gulecha VS, Upasani CD. Analgesic and anti-inflammatory activity of Argyreia speciosa root. Indian J Pharmacol. 2009:41(4):158.

55. Uche Fl, Aprioku JS. The Phytochemical Constituents, Analgesic and Antiinflammatory effects of methanol extract of Jatropha curcas leaves in Mice and Wister albino rats. JASEM. 2008;12(4).

56. Khathi A, Masola B, Musabayane CT. Effects of Syzygium aromaticum-derived oleanolic acid on glucose transport and glycogen synthesis in the rat small intestine. J diabetes. 2013;5(1):80-7

57. Raju GS, Moghal MR, Dewan SM, Amin MN, Billah M. Characterization of phytoconstituents and evaluation of total phenolic content, anthelmintic, and antimicrobial activities of Solanum violaceum Ortega. Avicenna J Phytomed. 2013;3(4):313.

\section{Publisher's Note}

Springer Nature remains neutral with regard to jurisdictional claims in published maps and institutional affiliations.

\section{Submit your manuscript to a SpringerOpen ${ }^{\circ}$ journal and benefit from:}

- Convenient online submission

- Rigorous peer review

- Open access: articles freely available online

- High visibility within the field

- Retaining the copyright to your article

Submit your next manuscript at $>$ springeropen.com 